\title{
The influence of emotional intelligence and trust on servant leadership
}

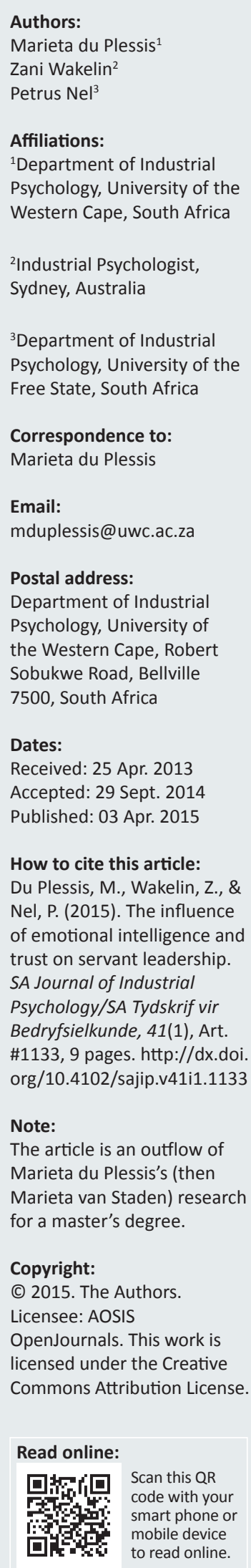

Orientation: Constructs were explored from a positive organisational behaviour (POB) paradigm. The aim of POB constructs is to develop and improve employees' psychological strengths, well-being and performance.

Research purpose: The objective of this research was to investigate the relationships between servant leadership, emotional intelligence and trust in the manager. A model depicting a sequential process of interrelationships amongst the constructs was proposed.

Motivation for the study: Organisations worldwide acknowledge the role that leadership and emotions play in psychological and physical well-being, as well as job performance of employees. Therefore, organisations need valid and workable interventions to assist their employees to function optimally in the work environment. By understanding the sequential relationships between servant leadership, emotional intelligence and trust, suggestions for such interventions were put forward.

Research approach, design and method: Both survey and statistical modelling methodologies were employed to guide the investigation. Standardised questionnaires were used to measure the three different constructs, based on the responses of 154 employees on a composite questionnaire.

Main findings: A high level of reliability was found for all the measurement scales utilised. The results of the structural equation model indicated that emotional intelligence and trust in the manager affected servant leadership.

Practical/managerial implications: Emotional intelligence training should form part of a necessary component in the development of servant leaders. Sufficient time should also be given to aspirant servant leaders to build relationships when coaching and mentoring their subordinates in order to build trust.

Contribution/value-add: The model of sequential relationships between the constructs assists in understanding the antecedents of servant leadership in the work environment.

\section{Introduction}

Confidence in contemporary business leadership has decreased following unethical actions on the part of leaders and resultant business failure (Liden, Wayne, Zhao \& Henderson, 2008; Reed, Vidaver-Cohen \& Coldwell, 2011). This has sparked an increased interest in the development of leaders who focus on the interests of their followers and organisations (Boyatzis \& McKee, 2005). The traditional organisational science approach demonstrates the deficit approach, which can be defined as the effort to understand and correct poor outcomes. This pathogenic perspective (Coetzee \& Cilliers, 2001; Vaillant, 2003) is gradually being replaced by a positive approach to both psychology and organisational behaviour (Luthans, 2002). The focus of the positive approach is on individual well-being and coping skills to effectively deal with changes, challenges and problems in organisations and in careers. Within this framework, leadership too is being approached from a more positive perspective, for example servant leadership (Greenleaf, 1996; Laub, 1999; Spears, 1998, 2004), spiritual leadership (Barrett, 1995, 1998; Giacalone \& Jurkiewicz, 2003) and authentic leadership (Avolio \& Gardner, 2005; B. George, 2003; Luthans \& Avolio, 2003).

A major precept of servant leadership proposes that followers will become healthier, wiser, freer, more autonomous and more likely to become servant leaders themselves (Greenleaf, 1970). The extent to which servant leadership fosters emotional health, organisational wisdom and self-determination provides key research opportunities to test these assertions. There also appear to be significant relationships between servant leadership and positive outcomes such as employees' extra effort, perceptions of organisational effectiveness (Barbuto \& Wheeler, 2006), 
trust (Beck, 2014; Schaubroeck, Lam \& Peng, 2011), team commitment (Dannhauser, 2007, 2009b; Mahembe, 2010), team organisational citizenship behaviour (Hu \& Liden, 2011; Mahembe, 2010; Vondey, 2010), self-efficacy (Beck, 2014), innovation (Vanderpyl, 2012), employees' satisfaction and experience of meaning (Drury, 2004; Hebert, 2003; Irving, 2005).

Goleman $(1995,1998)$ has noted that emotional intelligence is at the very centre of effective leadership. The positive leadership intelligence involves not only recognising emotions in oneself and others, but also knowing how and when emotions unfold and using this to lead accordingly (Luthans, Luthans, Hodgetts \& Luthans, 2002). For example, leaders who are capable of regulating their emotions are more likely to be adaptive and able to create an environment of trust and fairness (Luthans et al., 2002).

Accordingly, servant leadership and emotional intelligence can be linked to an organisational culture of trust (Luthans et al., 2002; Reinke, 2004). Lester and Brower (2003) explored the relationship between servant leadership and trust by specifically investigating the influence of subordinates' perceptions of their leaders' trust in them. Their findings supported their hypotheses that subordinates' perceptions of their leaders' trust in them (felt trustworthiness) are positively related to the subordinates' performance, organisational citizenship behaviour and job satisfaction. Consequently, the authors conclude that when employees perceive that they are trusted, they will work harder, go beyond the call of duty and be more content with their work.

In positive organisational behaviour (POB) it is not appropriate to study only the impact of positive predictors without linking the latter to positive outcomes (Luthans, 2002). In this study, the positive outcome is servant leadership and its associated predictors and antecedents (namely emotional intelligence and trust).

To date, there have been no other quantitative studies investigating the relationship between the constructs of servant leadership, emotional intelligence and trust in the manager. Parris and Peachey (2013) argue that servant leadership is a worthy area of study due to its positive outcomes for followers. Moreover, there is a lack of research aimed at understanding the antecedents of servant leadership behaviour (Reed et al., 2011).

\section{Literature review}

Servant leadership describes leaders' deep-rooted desire to make a positive difference in others' lives, their commitment to and skill in fostering spiritual recovery from hardship or trauma. Servant leaders employ a combination of awareness of surroundings and anticipation of consequences; they use sound reasoning and mental frameworks and they prepare an organisation to make a positive contribution to society through community development programmes (Barbuto \& Wheeler, 2006). Spears (2004) states that servant leadership involves feeling responsible to the world and actively contributing to the well-being of people and communities. This unpretentiously implies for the (servant) leader to put people first and this action eminently forms one of the seven servant leadership pillars conceptualised by Sipe and Frick (2009). These seven pillars constitute that servant leaders are individuals of character; they put people first, are skilled communicators, compassionate collaborators, use foresight, are systems thinkers and exert moral authority.

Thus, the typical servant leader does not see people as a means to serve themselves (Good, 2013), but conversely, the servant leader views their role to empower others to become better at what they do, to achieve greater levels of skill and ability and become better, more productive people in the process (Good, 2013), irrespective of the organisation or environment they are functioning in (Dannhauser, 2008). For this reason servant leadership is viewed as a positive approach to leadership within the POB framework.

Barbuto and Wheeler's (2006) research on the concept of servant leadership and the 11 potential characteristics of servant leadership resulted in the refinement of the servant leadership construct as a five-dimensional construct. The five dimensions of their servant leadership model are:

- Altruistic calling: a leader's innate desire to make a positive difference in others' lives.

- Emotional healing: a leader's commitment to and skill in fostering spiritual recovery from hardship or trauma.

- Wisdom: a combination of awareness of surroundings and anticipation of consequences. When these two characteristics are combined, leaders are adept at picking up cues from the environment and understanding their implications.

- Persuasive mapping: the extent to which leaders use sound reasoning and mental frameworks.

- Organisational stewardship: the extent to which leaders prepare an organisation to make a positive contribution to society through community development, development programmes, outreach and corporate social responsibility.

Servant leadership can be utilised as an appropriate leadership model in South Africa (Covey, 2006) as it is characterised by moral authority, humility, service and sacrifice in order to create trust and teamwork. Various studies have established that servant leadership has the potential to enhance interpersonal trust between workers and their managers (Chatbury, Beaty \& Kriek, 2011; Dannhauser, 2007, 2009b; Schaubroeck et al., 2011).

It is argued that a service-oriented philosophy of, and approach to, leadership are more likely to manifest once certain antecedents are in place (Beck, 2014). Beck's (2014) findings of characteristics, behaviours or life experiences that would predict servant leadership include: the job tenure of leaders influences the frequency of servant leader behaviour, servant leaders influence 
others through building trusting relationships, servant leaders demonstrate an altruistic mindset, servant leaders are typified by interpersonal competence (emotional intelligence) and leading from behind. Barbuto and Wheeler (2006) state that other sources could include variables such as emotional intelligence, sources of motivation, organisational culture and exposure to and mentorship of other servant leaders.

Goleman (1998) defines emotional intelligence as 'the capacity for organising one's own feelings and those of others, for motivating oneself, and for managing emotions well in oneself and in relationships' (p. 317). In the process and scientific debate to determine an operational model of emotional intelligence, two markedly different, yet related, models of emotional intelligence have been suggested. The first model is an 'ability model', which combines emotion with intelligence (Salovey \& Mayer, 1990); the second is what is termed a 'mixed model', which combines traits with social behaviours and competencies (Goleman 1995, 1998). In the current study, the mixed-model approach is utilised as a result of its value in organisational and leadership development, as suggested by Goleman (1995, 1998). The definition of emotional intelligence in this regard consists of three categories of abilities: evaluation and expression of emotion, regulation of emotion and using emotions in decision-making. Goleman (1998) suggests that emotional intelligence in the work situation is a multidimensional construct consisting of five components. These components are self-awareness, self-regulation, motivation, empathy and social skills (Goleman, 1995).

Despite the increasing interest in emotions and their impact on leadership style and performance, research investigating the role of emotion on employees and its influence on interworker relationships and different leadership styles has yet to be fully explored (Lewis, 2000). Some research on the role of emotional intelligence in transformational leadership exists, namely studies conducted by Leban and Zulauf (2004), Barling, Slater and Kelloway (2000) and Gardner and Stough (2002). In a literature review conducted by Winston and Hartsfield (2004) strong similarities between the constructs of emotional intelligence and five servant leadership models were found. These similarities include the leader's ability to appraise and express emotion and use emotion to enhance cognitive processes and the reflective regulation of emotions.

Likewise, research found that leaders who are able to identify and understand the emotions of others can influence the feelings of subordinates in such a way that enthusiasm, productivity, cooperation and trust in other employees are maintained (J.M. George, 2000). Baker (2009) established that servant leadership behaviour of the supervisor leads to increased utilisation by employees of coping mechanisms deemed specifically conducive to customer service. Furthermore, leaders who are able to understand and manage their emotions and display self-control act as role models for followers and in so doing enhancing the followers' trust and respect for the leader (Gardner \& Stough, 2002; Schlechter \& Strauss, 2008).

It is therefore argued that subsequent to the relationship between servant leadership and emotional intelligence, a relationship exists between emotional intelligence of the leader and subordinates' trust in the leader. Therefore, it is conceptually argued that trust in the leader can also be seen as an important correlate for the interdependence that exists between leaders and followers in servant leadership. Followers place their trust in the leader as a result of the leader's concern to place their followers' self-interest first (Dannhauser, 2009a; Farling, Stone \& Winston, 1999).

In servant leadership (like other leadership models) trust plays a pivotal role in the interdependence that exists between leaders and followers (Mayer, Davis \& Schoorman, 1995). Relationships built on trust and service are the basis for the influence of servant leadership (Beck, 2014; Dannhauser, 2009b; Sarkus, 1996). Greenleaf (1977) states that trust is central to servant leadership since leadership legitimacy forms with trust. The calling to serve leads one into an active role as servant, building trust not only between the leader and follower but also between followers (Spears, 1998).

Good (2013, p. 2) postulates that 'nothing builds trust faster than a servant attitude' because people know their leader genuinely cares about them and has their best interest at heart, even when they have to deal with problems. This corroborates studies conducted by Joseph and Winston (2005) which found a positive correlation between employee perceptions of servant leadership at an organisational level and leader trust. It was also found that employee perceptions of organisational servant leadership resulted in higher levels of trust in the leader than perceptions of non-servant leadership. The value of this finding is that it provides support for models proposing that servant leadership is one of the specific leadership behaviours that elicits trust from others (Beck, 2014; Cerff, 2004; Dannhauser, 2007, 2009b; Dannhauser \& Boshoff, 2006, 2007; Farling et al., 1999; Russell \& Stone, 2002).

From the preceding discussion on the respective constructs, it is hypothesised that servant leadership is a relational leadership style and it can be expected that individuals' perception of their manager's servant leadership behaviour would be higher if the manager had higher levels of emotional intelligence. However, this would not be the case if the individuals do not trust their manager. Therefore, it is proposed that emotional intelligence of the leader and followers' trust in said leader would influence their perception of the leader's servant leadership behaviour.

This leads to the research question and proposed theoretical framework (Figure 1) for this study: can a valid model be built of the sequential relationships amongst the combinations of variables and their dimensions, namely emotional 


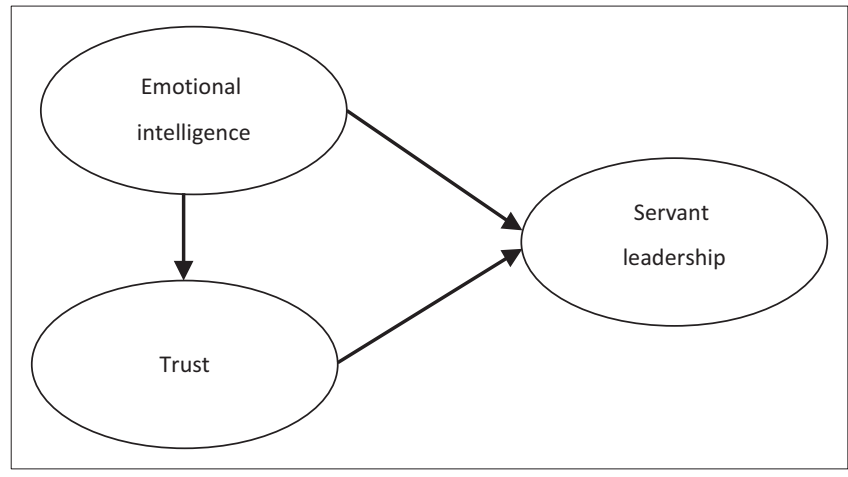

FIGURE 1: Theoretical framework of the relationship between emotional intelligence, trust and servant leadership.

intelligence, trust in the immediate supervisor and servant leadership, within the realm of positive organisational psychology?

\section{Research design \\ Research approach}

The data in this study was analysed by means of quantitative techniques. Primary data were collected through standardised questionnaires. The self-administered survey was the method employed in this study.

Although survey studies provide a broad overview of the phenomenon being studied, they lack the ability to evaluate the theoretical models developed through a literature review. To overcome this limitation, statistical modelling was combined with the survey study to validate the theoretical model.

\section{Research method}

\section{Research participants}

The research data were gathered in two separate private sector organisations in the media and pharmaceutical industries within the South African context. One of these organisations was located in the Western Cape and the other in Gauteng. The sample consisted of 101 (65.6\%) female respondents and $53(34.4 \%)$ male respondents. Most of the respondents indicated their home language to be Afrikaans (60.8\%), followed by English (27.5\%). Of the respondents, $1.9 \%$ indicated isiXhosa as their home language. Regarding ethnicity, the largest proportion of respondents was white people $(62.5 \%)$, followed by people of mixed-race (23\%) and black people $(12.5 \%)$. The education breakdown indicates that most respondents $(39.7 \%)$ had a Grade 12 qualification or equivalent, followed by $29.1 \%$ with a tertiary certificate or diploma and $12.6 \%$ with a bachelor's degree. The mean age of respondents was 34 years $(S D=10.5)$. The reporting period to current manager reflects a mean period of two years $(\mathrm{SD}=32.14)$. Of the respondents, $57.9 \%$ have been reporting to their current manager for one year or less.

After distributing the questionnaires to the population, a total of 154 candidates with usable responses were included in the sample. This represented a $34 \%$ response rate. The sample was representative of the population in which the questionnaires were used.

\section{Ethics considered}

Research participants received an addressed envelope, containing a letter from the researcher stating the purpose of the research as well as a letter from the organisation stating their support for the research. Furthermore, participants received a questionnaire and a pre-addressed envelope for returning the completed questionnaire. The questionnaire was not coded or marked in any way; hence, anonymity of participants was protected.

The accompanying letter from the researcher clearly indicated that participation in the research was on a voluntary basis. It was also stated that should participants not agree to take part in the study, they could or were allowed to discard the questionnaire without having to give notice to the researcher. By completing the questionnaire, the participant consented to taking part in the study. The research participants were not endangered in any way neither was there any risk to their physical, emotional and mental health or job security.

\section{Measuring instruments}

Three questionnaires were identified through the literature review as being reliable, valid and applicable to this study. A general discussion of each questionnaire's properties in terms of content, structure and psychometric features, as presented in the literature, follows.

Servant leadership: The Servant Leadership Questionnaire (SLQ) developed by Barbuto and Wheeler (2006) consists of 23 items. The questionnaire was originally developed to operationalise the servant leadership construct and the servant leadership characteristics were reviewed by these authors. Items for these characteristics were validated and created. Factor analysis reduced the data to five unique subscales which were used to test reliability, convergent, divergent and predictive validity. The rater version of the subscales demonstrated reliabilities (alpha values) ranging from 0.82 to 0.92 (Barbuto \& Wheeler, 2006) and an alpha value of less than 0.80 in a South African context (Mahembe \& Engelbrecht, 2013). Subscale inter-correlations ( $r$ ) ranged from 0.47 (for persuasive mapping and emotional healing) to 0.71 (for altruistic calling and emotional healing) for rater versions of the SLQ (Barbuto \& Wheeler, 2006). The SLQ consists of a leader self-report version and an 'other' rater version. However, both versions of the SLQ consist of the same questions, with only the frame of reference differing. The former is answered from the leader's perception of their own levels of exhibiting servant leadership and the latter from the employee's perception of their leader demonstrating certain servant leadership behaviours.

For the purpose of this study the rater version was utilised, as respondents were asked to evaluate their supervisor's servant leadership levels. The structure of this instrument includes five factors, namely altruistic calling, emotional healing, wisdom, 
persuasive mapping and organisational stewardship. Examples of items measuring servant leadership include (1) My manager puts my best interest ahead of his or her own and (2) My manager believes that the organisation needs to play a moral role in society. The SLQ utilised a seven-point frequency Likert scale. This scale had the following anchors: (1) never, (2) seldom, (3) sometimes, (4) unsure, (5) often, (6) mostly and (7) always. The responses on the items were then calculated in order to obtain the respective subscale scores and the total servant leadership score.

Emotional intelligence: Leader emotional intelligence was measured by a 30-item Emotional Intelligence Index (EQI), developed by Rahim et al. (2002). For the purpose of this study the rater version of this instrument was utilised, which means that employees were asked to rate their immediate supervisor's emotional skills. The five dimensions of the structure of the scale were self-awareness, self-regulation, motivation, empathy and social skills. Rahim and Minors (2003) reported reliabilities for the subdimensions ranging from 0.85 to 0.93 . Rahim et al. (2002) also reported Cronbach's alpha reliabilities for the subscales ranging from 0.58 to 0.90 in a study that was completed in six countries $(n=1395)$, including South Africa. Examples of items measuring emotional intelligence include: (1) My manager keeps his or her distressing emotions in check and (2) My manager expresses feelings in a way that inspires peak performance. The EQI utilised a seven-point intensity Likert scale with the following anchors: (1) strongly disagree, (2) disagree, (3) slightly disagree, (4) undecided, (5) slightly agree, (6) agree and (7) strongly agree. Responses were summed to achieve the respective subscale scores and the total emotional intelligence score.

Trust in the immediate supervisor: Trust was measured by the Workplace Trust Survey (WTS), developed by Ferres (2001). The original 36-item questionnaire was developed using focus group narratives and content analysis, which transcribed obtained 'trust themes' into items measuring trust at organisational, managerial and co-worker levels. Reliability for these three themes ranged from 0.93 to 0.95 . The questionnaire underwent further validation in South Africa ( $n=417$ ) (Dannhauser, 2007; Dannhauser \& Boshoff, 2007, 2008) and Australia $(n=496)$ (Ferres \& Travaglione, 2003). Cronbach's alpha coefficients for the validation studies ranged between 0.90 and 0.97 . For the purpose of this study, only the trust in the immediate supervisor subscale was utilised. This subscale comprises 12 items. Example of these items include: (1) I feel that my manager is available when needed and (2) I act knowing that my manager will keep his or her word. Items were scored and summed on the same seven-point Likert scale as the EQI, namely (1) strongly disagree, (2) disagree, (3) slightly disagree, (4) undecided, (5) slightly agree, (6) agree and (7) strongly agree.

\section{Research procedure}

Data collection: The sampling method employed for this study was non-probability sampling. This sampling technique was chosen due to the constraints of gathering data in private sector organisations, where the researcher did not have direct access to the candidates. This study followed a hard-copy approach in distributing the questionnaires, as this was the expressed preference of the private sector organisations. The survey consisted of four sections that had to be completed by members of the sample. Thus, the composite questionnaire (comprising of a biographical section and the SLQ, EQI and WTS) constituted the measuring instrument. Surveys were translated into Afrikaans and presented to participants in both English and Afrikaans. Instructions were provided on the cover page of the questionnaire to ensure respondents of confidentiality and anonymity and also to obtain informed consent.

\section{Statistical analysis}

All the analysis related to both the measurement models and structural models was conducted using LISREL 8.80 (Jöreskog, 2006). A test of multivariate normality was conducted to determine whether the data violated the assumption of normality (Jöreskog, 2006). The results suggested that the data deviated from normality in terms of skewness and kurtosis. Hence, the robust maximum likelihood method of estimation was used to estimate the various models (Brown, 2006). Several fit indices were used, including the Satorra-Bentler scaled chi-square, root mean square error of approximation (RMSEA), standardised root-mean square residual (SRMR), comparative fit index (CFI), and the goodness of fit index (GFI). Values close to 0.95 for GFI and CFI are considered indicative of good model fit. It is suggested that values close to 0.06 are indicative of acceptable fit for RMSEA, whilst values less than 0.08 are acceptable for SRMR (Hu \& Bentler, 1999). In addition, Akaike's information criterion (AIC) is used in the comparison of competing measurement and structural models with smaller values representing a better fit for the proposed model (Byrne, 2006).

Cronbach's alpha $(\alpha)$ was used to estimate the reliability associated with each of the dimensions related to the constructs investigated in the current study. Reliability estimates that are 0.70 and higher are indicative of good reliability. However, estimates as low as 0.60 may be acceptable when conducting exploratory research (Hair, Black, Babin, Anderson \& Tatham, 2006, pp. 137, 778).

\section{Results}

\section{Reliability analysis}

From the Cronbach's alpha reliability analysis it was clear that all three of the scales have acceptable reliabilities. The alpha values are 0.98 for the emotional intelligence scale, 0.94 for the trust scale and 0.97 for the servant leadership scale.

\section{Evaluating the measurement model}

Before evaluating the appropriateness of the proposed structural model, as depicted in Figure 1, the current study first determined the degree of fit associated with several measurement models. The current study employed 
TABLE 1:Goodness-of-fit statistics of the competing measurement models.

\begin{tabular}{lllllll}
\hline Model & S-B $\chi^{2}$ & $d \boldsymbol{f}$ & CFI & RMSEA & SRMR & AIC \\
\hline 1 & 447.88 & 206 & 0.98 & 0.088 & 0.054 & 541.88 \\
2 & 159.4 & 74 & 0.99 & 0.087 & 0.038 & 221.4 \\
3 & 112.57 & 69 & 0.99 & 0.064 & 0.03 & 184.57 \\
\hline
\end{tabular}

Note: S-B $\chi^{2}$, Satorra-Bentler scaled chi-square; $d f$, degrees of freedom; $\mathrm{CFI}$, comparative fit index; RMSEA, root mean square error of approximation; SRMR, standardised root mean square residual; AIC, Akaike's information criterion.

TABLE 2: Goodness-of-fit statistics of the structural model.

\begin{tabular}{llllll}
\hline S-B $\chi^{2}$ & $d f$ & CFI & RMSEA & SRMR & AIC \\
\hline 112.57 & 69 & 0.99 & 0.064 & 0.03 & 184.57 \\
\hline
\end{tabular}

Note: S-B $\chi^{2}$, Satorra-Bentler scaled chi-square; $d f$, degrees of freedom; $\mathrm{CFI}$, comparative fit index; RMSEA, root mean square error of approximation; SRMR, standardised root mean square residual; AIC, Akaike's information criterion.

confirmatory factor analysis to evaluate goodness of fit associated with these measurement models. Three measurement models were compared. Only when a measurement model shows acceptable fit can it be used to evaluate the structural model (Hair et al., 2006, p. 845).

Model 1 consisted of three latent variables (servant leadership, emotional intelligence and trust in the manager). Servant leadership was measured using the five dimensions associated with the construct, whilst emotional intelligence was measured by using its five subdimensions. Finally, trust in the manager was measured by 12 items related to the construct. From Table 1 it is clear that, although this model shows acceptable fit with regard to CFI (0.98), it shows lack of fit in terms of both the RMSEA and SRMR, which are higher than the recommended values. It was therefore decided to first employ item parcelling (for trust in the manager) to try and improve model fit. Item parcelling has the potential to improve model fit because it reduces the complexity of the measurement model and models with fewer variables have the potential for better fit (Hair et al., 2006, p. 826). It is important to note that parcelling should only be done when the construct, in this case trust in the manager, is unidimensional, which has been established for this construct (Ferres \& Travaglione, 2003; Dannhauser, 2007). Hence, Model 2 only differs from Model 1 in that trust in the manager was measured using four composite item parcels. Unfortunately, this did not result in much improvement of the fit of the model (See Table 1), especially with regard to the unacceptably high value associated with RMSEA.

In addition to using item parcels to improve model fit, researchers can consult modification indices (Hair et al., 2006, p. 797). Modification indices may indicate the possible origin of the observed misfit associated with the measurement model (Byrne, 1998, p. 98). In the current study, the modification indices suggested that correlating the errors of certain dimensions related to the emotional intelligence construct (self-regulation with social skills, empathy and motivation, social skills with empathy and self-awareness with empathy) would lead to an improvement in model fit. This seems plausible given the fact that:

error covariances can reflect overlapping content between two items on a measuring instrument. Such redundancy can

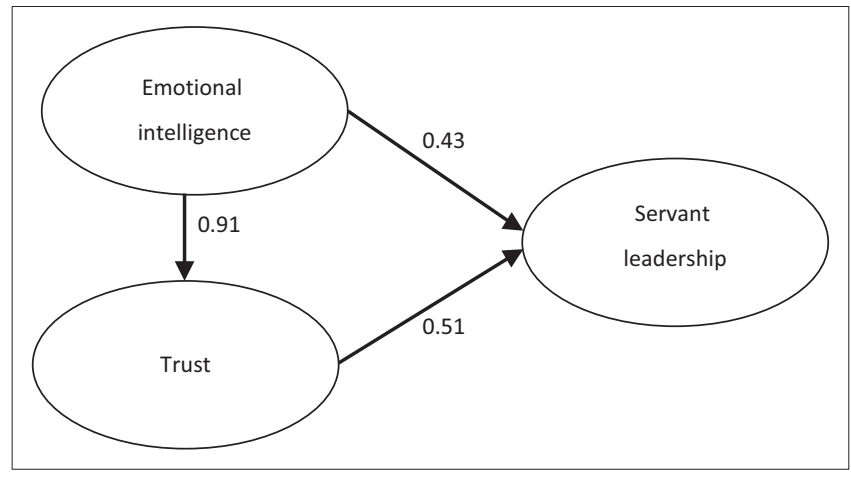

FIGURE 2: Path coefficients of the structural model with emotional intelligence, trust and servant leadership.

result from items that, although essentially asking the same question, have content that is worded slightly differently. (Byrne, 2005, p. 22)

Hence, it is likely that, although these dimensions measure different aspects related to emotional intelligence, they still overlap in terms of measuring emotional intelligence in general. Hence, Model 3 only differs from Model 2 in that the errors of the previously mentioned emotional intelligence dimensions were correlated. From Table 1 it is evident that this has led to a much more appropriate measurement model, with all the approximate fit indices well within the suggested cut-offs. In addition, Model 3 had the smallest value associated with AIC, indicating that it was the better fitting model. It was therefore decided that the testing of the structural model would be based on Model 3.

\section{Evaluating the structural model}

The theoretical model, as depicted in Figure 2, was evaluated using a structural model. Model 3, which was identified as the best fitting measurement model, was used to evaluate the appropriateness of the proposed structural model. From Table 2 it is evident that this model fitted the data well.

\section{Discussion \\ Outline of the results}

The aim of this study was to determine the relationships between emotional intelligence, trust in the manager and servant leadership. The results of the analysis suggest that significant relationships can be found between emotional intelligence, trust and servant leadership. Furthermore, the path coefficients of the best fitting and most parsimonious model indicate that emotional intelligence and trust have a statistically significant positive relationship with servant leadership.

The relationship between emotional intelligence and servant leadership has not been extensively studied (Barbuto, Gottfredson \& Searle, 2014). The existing wealth of literature, however, does suggest a significant relationship between emotional intelligence and leadership (mostly transformational leadership) (Goleman, 1998; Leban \& 
Zulauf, 2004). These sources conclude that supervisors and managers with a high level of emotional intelligence are seen by subordinates as better leaders. The results of the current study provide evidence for the relationship between emotional intelligence and servant leadership. Respondents who rated their manager as having a high level of emotional intelligence also rated their manager as exhibiting a high level of servant leadership. This contradicts the finding of Barbuto et al. (2014), who found no significant relationship between emotional intelligence of the leader and followers' perception about their leader's servant leadership behaviour.

The relationship between emotional intelligence and trust in the immediate supervisor was also significant. This confirms the conceptual link between emotional intelligence and trust in the immediate supervisor. Leaders who are able to understand and manage their emotions and display self-control act as role models for followers; in so doing they enhance the followers' trust and respect for the leader (Gardner \& Stough, 2002). This relationship between emotional intelligence and trust in the immediate supervisor $(t=2.6 ; p<0.05)$ was correspondingly found in a South African context $(n=178)$ by Schlechter and Strauss (2008).

A significant relationship was also found between servant leadership and trust in the immediate supervisor. This confirms the conceptual relationship between servant leadership and trust in the immediate supervisor as suggested in the literature (Farling et al., 1999; Russell \& Stone, 2002). Farling et al. (1999) proposed that followers of servant leadership would place their trust in the leader as a result of the leader's concern that puts the followers' self-interest first. In this regard, the servant leader does not persuade the follower to trust, but rather portrays their authentic behaviours and values, such as emotional intelligence, appreciation of others, empowerment, integrity, internal self-change, persuasion and service (Russell \& Stone, 2002), as an example to others. In fact, Beck (2014) argues that servant leaders influence others through developing trusting relationships.

Greenleaf (1977) perceived servant leadership as both a product and an antecedent of leader and organisational trust. This may be because servant leadership increases perceptions of leader trustworthiness, which has a reciprocal relationship with leader trust (Joseph \& Winston, 2005). Servant leadership behaviours include expressing authenticity, humility and providing guidance to employees, hence leaving employees with a sense of being empowered by their leader (Van Dierendonck, 2011). With these characteristics in mind, it can be understood that it takes time for a leader to authentically nurture and exhibit servant leadership behaviours (Barrett, 1995, 1998). Only when the dimensions of service, trust and emotional intelligence are aligned and fully integrated within the leader does such a leader ascend to meaningfulness. Therefore, much of the findings seem to be attributable to how long a (servant) leader has been in their specific role. To this end both Baker (2009) and Beck
(2014) found that the longer a leader is in a leadership role, the more frequent the servant leader behaviours such as trust, coping, emotional intelligence and altruism are perceived by followers. Consequently, it most likely also applies to the findings of this study, especially when one considers that about half $(42.1 \%)$ of the respondents have been reporting to their current manager for more than one year. Time could subsequently be offered as an interpretation for the results on the relationships between the variables in this study.

Inspection of the proposed relationships between the latent variables revealed that there are significant paths between emotional intelligence, servant leadership and trust. In light of these results, the following possible interpretations can be made: (1) that trust is significantly influenced by explicit leader emotional intelligence, (2) that the subordinate's level of trust in their manager has a substantial impact on the subordinate's perception of their managers servant leadership levels and (3) that explicit leader emotional intelligence and the trust that subordinates have in their leader have a significant impact on how they view their supervisor or manager's level of servant leadership. These possible deductions are consistent with the view that the reporting period to current manager could influence an individual's perception of the behaviours that leaders may display and to what extent the leader has been able to develop trust in the follower.

\section{Practical implications}

The value of this study lies in the understanding that there are necessary antecedents to the effective practice of servant leadership, which corroborates Beck's (2014) finding. Therefore, it can be concluded from this study that emotional intelligence training should constitute a necessary step in the development of servant leaders. Despite controversy on the topic, research has proved that emotional intelligence, like self-efficacy, is acquirable and that it can be successfully developed through training (Chrusciel, 2006; Jonker, 2009; Luthans, 2011; Luthans, Youssef \& Avolio, 2007). Sufficient time should also be given to aspirant leaders to build relationships when coaching and mentoring their subordinates in order to build trust. This will lay the necessary foundation for becoming a servant leader.

From an applied organisational perspective the 'good to great' (Collins, 2001) and seven servant leadership pillar studies (Sipe \& Frick, 2009) suggest that companies with a component of servant leadership perform better than the average organisation. Companies with servant leadership as a cornerstone of their organisational model performed more than twice as well as other companies (Collins, 2001; Lichtenwalner, 2012; Sipe \& Frick, 2009).

\section{Limitations and recommendations}

Future research studies utilising the survey method should aim to implement measures to prevent mono-method (and possible response set) bias. Furthermore, due 
to the cross-sectional nature of the data, causality of the relationships between the variables could not be determined.

It is evident that opportunities exist for future studies to further explore the relationships between emotional intelligence, trust and servant leadership. There exists an opportunity to explore a number of other constructs and their relationships with the constructs utilised in this study.

\section{Conclusion}

In previous decades, the notion and presence of well-being in organisations was completely disregarded: emotions were perceived as irrational factors to be excluded from the work environment. The present research study forms part of a novel movement in organisational research that attempts to shift the focus from problems and deficiencies to a proactive model focusing on how to make organisations and individuals thrive.

The findings in this study demonstrate that servant leadership can be measured in a workplace setting and correlates positively with two other organisational constructs, namely emotional intelligence and trust. This provides useful information for practicable leadership development interventions in organisations.

With regard to servant leadership, Barbuto and Wheeler (2006) argue that further antecedents of servant leadership could include variables such as sources of motivation, flexibility and openness to experience or situational variables such as education, basis of social power, early childhood experiences, organisational culture and exposure to and mentorship of other servant leaders. Future research could include more of these antecedents in order to assist in scientifically creating the servant leadership construct and measure.

\section{Acknowledgements}

The researcher wishes to acknowledge the reviewers of this article and section editor of the journal for feedback and suggestions for improvements. Gratitude is also expressed to the sample respondents and two organisations where data was gathered for the contribution to the study.

\section{Competing interests}

As authors, we declare that we have no financial or personal relationship(s) that may have inappropriately influenced us in writing this article.

\section{Authors' contributions}

M.d.P. (University of the Western Cape) was responsible for all writing, data gathering and data analysis. Z.W. (Industrial Psychologist) was the supervisor of this research study and revised and updated the literature and information on the constructs together with some rewriting of the text. P.N. (University of the Free State) assisted with the statistical analysis and revising the methodology and results section.

\section{References}

Avolio, B.J., \& Gardner, W.L. (2005). Authentic leadership development: Getting to the root of positive forms of leadership. Leadership Quarterly, 16, 315-338. http://dx.doi.org/10.1016/j.leaqua.2005.03.001

Baker, M. (2009). The relationship between servant leadership, role stress and coping in subordinate service roles. Unpublished master's thesis, Department of Industrial Psychology, University of Stellenbosch, Stellenbosch, South Africa.

Barbuto, J.E., Gottfredson, R.K., \& Searle, T.P. (2014). An examination of emotional intelligence as an antecedent of servant leadership. Journa of Leadership \& Organizational Studies, 21(3), 315-323. http://dx.doi. org/10.1177/1548051814531826

Barbuto, J.E., \& Wheeler, D.W. (2006). Scale development and construct clarification of servant leadership. Group \& Organization Management, 31(3), 300-326. of servant leadership. Group \& Organization
$\mathrm{http} / / / \mathrm{dx}$.doi.org/10.1177/1059601106287091

Barling, J., Slater, E., \& Kelloway, E.K. (2000). Transformational leadership and emotional intelligence: An exploratory study. Leadership \& Organization Development Journal, 21(3), 157-161. http://dx.doi.org/10.1108/01437730010325040

Barrett, R. (1995). A guide to liberating your soul. Alexandria, VA: Fulfilling Books.

Barrett, R. (1998). Liberating the corporate soul: Building a visionary organization. Boston, MA: Butterworth-Heinemann.

Beck, C.D. (2014). Antecedents of servant leadership: A mixed methods study. Journal of Leadership \& Organizational Studies, 21(3), 299-314. http://dx.doi. org/10.1177/1548051814529993

Boyatzis, R., \& McKee, A. (2005). Resonant leadership: Renewing yourself and connecting with others through mindfulness, hope, and compassion. Boston, MA: connecting with others through
Harvard Business School Press.

Brown, T.A. (2006). Confirmatory factor analysis for applied research. New York, NY: Guilford Press. http://dx.doi.org/10.1080/00036810600603377

Byrne, B.M. (1998). Structural equation modelling with LISREL, PRELIS, and SIMPLIS Basic concepts, applications, and programming. Mahwah, NJ: Erlbaum.

Byrne, B.M. (2005). Factor analytic models: Viewing the structure of an assessment instrument from three perspectives. Journal of Personality Assessment, 85, 1732. http://dx.doi.org/10.1207/s15327752jpa8501_02

Byrne, B.M. (2006). Structural equation modelling with EQS: Basic concepts, applications and programming. (2nd edn.). Mahwah, NJ: Erlbaum.

Cerff, K. (2004). Establishing trust during organizational transformation: A single case study. International Leadership Studies Conference Proceedings, August 2004. Virginia Beach, VA: School of Leadership Studies, Regent University.

Chatbury, A., Beaty, D., \& Kriek, H.S. (2011). Servant leadership, trust and implications for the 'Base-of-the-pyramid' segment in South Africa. South African Journal of Business Management, 42(4), 57-62.

Chrusciel, D. (2006). Considerations of emotional intelligence (EI) in dealing with change decision management. Management Decision, 44(5), 644-657. http:// dx.doi.org/10.1108/00251740610668897

Coetzee, S., \& Cilliers, F. (2001). Psychofortology: Explaining coping behavior in organizations. The Industrial-Organizational Psychologist, 38, 62-68.

Collins, J. (2001). Good to great. New York, NY: HarperCollins.

Covey, S.R. (2006). Servant leadership: Use your voice to serve others. Leadership Excellence, 23(12), 5-6.

Dannhauser, Z. (2007). The relationship between servant leadership, trust, team commitment and unit effectiveness. Unpublished doctoral dissertation, Department of Industrial Psychology, University of Stellenbosch, Stellenbosch, Sopartment Africa.

Dannhauser, Z. (2008, September). Differences and similarities between transformational and servant leadership. Paper presented at the 5th International Conference on Contemporary Business (ICCB), Somerset West, South Africa.

Dannhauser, Z. (2009a). The learning organisation. In R. Nel (Ed.), Puppets or people: People and organisational development: An integrated approach to people and organisational development (pp. 106-122). Cape Town, South Africa: Juta Publishers.

Dannhauser, Z. (2009b). Empowering the organisation through servant leadership. Leading with service, trust and commitment: A positive organisational approach. Saarbrücken, Germany: VDM Verlag Publishers.

Dannhauser, Z., \& Boshoff, A.B. (2006, July). A model of the relationship between servant leadership, trust, and team commitment. Paper presented at the 13th Annual International Conference on Advances in Management (ICAM) Proceedings, Lisbon, Portugal.

Dannhauser, Z., \& Boshoff, A.B. (2007). Structural equivalence of the Barbuto and Wheeler Servant Leadership Questionnaire on North American and South African samples. International Journal of Leadership Studies (IJLS), 2(2), 148-168.

Dannhauser, Z., \& Boshoff, A.B. (2008). Rejoinder: Comments on Barbuto, Story, and Gifford's 'Response'. International Journal of Leadership Studies, 4(1), 104-106.

Drury, S.L. (2004). Servant leadership and organizational commitment: Empirical findings and workplace implications. Proceedings of the 2004 Servant Leadership Research Roundtable Proceedings, Regent University, School of Leadership Studies. Retrieved March 03, 2013, from http://www.regent.edu/acad/global/ Studies. Retrieved March 03, 2013, from http://www.regent.edu/
publications/sl_proceedings/2004/drury_servant_leadership.pdf. 
Farling, M.L., Stone, A.G., \& Winston, B. (1999). Servant leadership: Setting the stage for empirical research. Journal of Leadership Studies, 6(1/2), 49-72. http://dx.doi. for empirical research. Journal of Lea
org/10.1177/107179199900600104

Ferres, N. (2001). The development and validation of the Workplace Trust Survey (WTS): Combining qualitative and quantitative methodologies. Unpublished master's dissertation, Department of Management, University of Newcastle, Australia.

Ferres, N., \& Travaglione, T. (2003, December). The development and validation of the workplace trust survey (WTS): Combining qualitative and quantitative methodologies. Paper presented at the APROS, Mexico.

Gardner, L., \& Stough, C. (2002). Examining the relationship between leadership and emotional intelligence in senior level managers. Leadership \& Organization Development Journal, 23(2), 68-78. http://dx.doi.org/10.1108/ 01437730210419198

George, B. (2003). Authentic leadership. San Francisco, CA: Jossey-Bass.

George, J.M. (2000). Emotions and leadership: The role of emotional intelligence. Human Relations, 53, 1027-1041.

Giacalone, R.A., \& Jurkiewicz, C.L. (2003). Toward a science of workplace spirituality. In R.A. Giacalone, \& C.L. Jurkiewicz (Eds.), Handbook of workplace spirituality and organizational performance (pp. 3-28). New York, NY: M.E. Sharp.

Goleman, D. (1995). Emotional intelligence: Why it can matter more than IQ. New York, NY: Bantam.

Goleman, D. (1998). Working with emotional intelligence. London, United Kingdom Bloomsbury.

Good, D. (2013). The good life - 5 reasons why servant leadership works. Retrieved January 12, 2013, from http://goodlifeblog.blogspot.com/2013/08/5-reasonswhy-servant-leadership-works.html-.VKqcTXuUbX9

Greenleaf, R.K. (1970). The servant as leader. Indianapolis, IN: The Robert Greenleaf Center.

Greenleaf, R.K. (1977). Servant leadership: A journey into the nature of legitimate power and greatness. New York, NY: Paulist Press.

Greenleaf, R.K. (1996). The crisis of leadership. In D.M. Frick, \& L.C. Spears (Eds.), On becoming a servant leader (pp. 287-298). San Francisco, CA: Jossey-Bass.

Hair, J.F., Black, B., Babin, B., Anderson, R.E., \& Tatham, R.L. (2006). Multivariate dato analysis. (6th edn.). Upper Saddle River, NJ: Prentice Hall.

Hebert, S.C. (2003). The relationship of perceived servant leadership and job satisfaction from the follower's perspective. Dissertation Abstracts International, 64(11), 4118. (UMI No. 3112981)

Hu, J., \& Liden, R.C. (2011). Antecedents of team potency and team effectiveness: An examination of goal and process clarity and servant leadership. Journal of Applied Psychology, 96(4), 851-862. http://dx.doi.org/10.1037/a0022465

Hu, L., \& Bentler, P.M. (1999). Cut-off criteria for fit indexes in covariance structure analysis: Conventional criteria versus new alternatives. Structural Equation Modeling, 6, 1-55

Irving, J.A. (2005). Servant leadership and the effectiveness of teams. Unpublished doctoral dissertation, School of Leadership Studies, Regent University, Virginia Beach, VA.

Jonker, C.S. (2009). The effect of an emotional intelligence development programme on accountants. SA Journal of Human Resource Management/SA Tydskrif vi Menslikehulpbronbestuur, 7(1), 157-165.

Jöreskog, K.G. (2006). Formal inference-based recursive modeling [LISREL]. Hillsdale, $\mathrm{NJ}$ : Lawrence Erlbaum Associates.

Joseph, E.E., \& Winston, B.E. (2005). A correlation of servant leadership, leader trust, and organizational trust. Leadership \& Organization Development Journal, 26(1) and organizational trust. Leadership \& Organization Devel

Laub, J.A. (1999). Assessing the servant organization: Development of the servant organizational leadership (SOLA) instrument. Florida Atlantic University. Dissertation Abstracts International (ProQuest Digital Dissertations), 60(02), Dissertation Abstracts In
308A. (UMI No. 9921922)

Leban, W., \& Zulauf, C. (2004). Linking emotional intelligence abilities and transformational leadership style. Leadership \& Organisation Developmen Journal, 25(7), 554-564. http://dx.doi.org/10.1108/01437730410561440

Lester, S.W., \& Brower, H.H. (2003). In the eyes of the beholder: The relationship between subordinates' felt trustworthiness and their work attitudes and behaviors. Journal of Leadership \& Organizational Studies, 10(2), 17-34. http://dx.doi.org/10.1177/107179190301000203

Lewis, K.M. (2000). When leaders display emotion: How followers respond to negative emotional expression of male and female leaders. Journal of Organizational Behavior, 21, 221-234. http://dx.doi.org/10.1002/(SICI)10991379(200003)21:2\%3C221::AID-JOB36\%3E3.0.CO;2-0

Lichtenwalner, B.S. (2012). Three studies prove servant leadership is good for business. Retrieved February 04, 2013, from http://modernservantleader.com

Liden, R.C., Wayne, S.J., Zhao, H., \& Henderson, D. (2008). Servant leadership: Development of a multidimensional measure and multi-level assessment. The Leadership Quarterly, 19(2), 161-177. http://dx.doi.org/10.1016/j.leaqua. Leadership 2008.01 .006
Luthans, F. (2002). Positive organizational behavior: Developing and managing psychological strengths. Academy of Management Executive, 16, 57-75. psychological strengths. Academy of Man
http://dx.doi.org/10.5465/AME.2002.6640181

Luthans, F. (2011). Organizational behavior: An evidence-based approach. (12th edn.). New York, NY: McGraw-Hill//rwin. http://dx.doi.org/10.1080/01608061.2011. 619421

Luthans, F., \& Avolio, B. (2003). Authentic leadership development. In K.S. Cameron, J.E. Dutton, \& R.E. Quinn (Eds.), Positive organizational scholarship: Foundations of a new discipline, (pp. 241-258). San Francisco, CA: Berrett-Koehler Publishers, Inc.

Luthans, F., Luthans, K., Hodgetts, R.M., \& Luthans, B.C. (2002). Positive approach to leadership (PAL). Journal of Leadership Studies, 8, 3-20. http://dx.doi. org/10.1177/107179190100800201

Luthans, F., Youssef, C., \& Avolio, B. (2007). Psychological capital. Oxford, United Kingdom: Oxford University Press.

Mahembe, B. (2010). The relationship between servant leadership, team commitment, team citizenship behaviour and team effectiveness: An exploratory study. Unpublished master's thesis, Department of Industrial Psychology, University of Stellenbosch, Stellenbosch, South Africa.

Mahembe, B., \& Engelbrecht, A.S. (2013). A confirmatory factor analytical study of a servant leadership measure in South Africa. South African Journal of Industrial Psychology, 39(2), Art.\#1127, 8 pages. http://dx.doi.org/10.4102/sajip.v39i2.1127

Mayer, R.C., Davis, J.H., \& Schoorman, F.D. (1995). An integrative model of organizational trust. Academy of Management Review, 20(3), 709-734. organizational trust. Academy of Management
http://dx.doi.org/10.5465/AMR.1995.9508080335

Parris, D., \& Peachey, J. (2013). A systematic literature review of servant leadership theory in organizational contexts. Journal of Business Ethics, 113, 377-393. http://dx.doi.org/10.1007/s10551-012-1322-6

Rahim, M.A., \& Minors, P. (2003). Effects of emotional intelligence for quality and problem solving. Managerial Auditing Journal, 18(2), 150-155. http://dx.doi. org/10.1108/02686900310455146

Rahim, M.A., Psenicka, C., Polychroniou, P., Zhao, J.H., Yu, C.S., Chan, K.A. et al. (2002). A model of emotional intelligence and conflict management strategies: $A$ study in seven countries. International Journal of Organizational Analysis, 10(4), 302-326. $\mathrm{http} / / / \mathrm{dx}$.doi.org/10.1108/eb028955

Reed, L.L., Vidaver-Cohen, D., \& Coldwell, S.R. (2011). A new scale to measure executive servant leadership: Development, analysis, and implications for research. Journal of Business Ethics, 101, 415-434. http://dx.doi.org/10.1007/s10551-011-0813-1

Reinke, S. (2004). Service before self: Towards a theory of servant leadership. Global Virtue Ethics Review, 5(3-4), 30-58.

Russell, R.F., \& Stone, A.G. (2002). A review of servant leadership attributes: Developing a practical model. The Leadership \& Organisation Development Developing a practical model. The Leadership \& Organisation Devel
Journal, 23(3), 145-157. http://dx.doi.org/10.1108/01437730210424

Salovey, P., \& Mayer, J.D. (1990). Emotional intelligence. Imagination, Cognition and Personality, 9, 185-211. http://dx.doi.org/10.2190/DUGG-P24E-52WK-6CDG

Sarkus, D.J. (1996). Servant-leadership in safety: Advancing the cause of and practice. Professional Safety, 41(6), 26-32.

Schaubroeck, J., Lam, S.S.K., \& Peng, A.C. (2011). Cognition-based and affect-based trust as mediators of leader behavior influences on team performance. Journal of Applied Psychology, 96, 863-871. http://dx.doi.org/10.1037/a0022625

Schlechter, A.F., \& Strauss, J.J. (2008). Leader emotional intelligence, transformational leadership, trust and team commitment: Testing a model within a team context. SA Journal of Industrial Psychology, 34(1), 42-53. http://dx.doi.org/10.4102/sajip. v34i1.418

Sipe, J.W., \& Frick, D.M. (2009). Seven pillars of servant leadership: Practicing the wisdom of leading by Serving. Mahwah, NJ: Paulist Press.

Spears, L.C. (1998). Insights on leadership: Service, stewardship, spirit, and servant leadership. New York, NY: J. Wiley.

Spears, L.C. (2004). The understanding and practice of servant leadership. In L.C. Spears, \& M. Lawrence (Eds.), Practicing servant leadership: Succeeding through trust, bravery and forgiveness (pp. 9-24). San Francisco, CA: Jossey-Bass.

Vaillant, G.E. (2003). Mental health. American Journal of Psychiatry, 160(8), 1373-1384. http://dx.doi.org/10.1176/appi.ajp.160.8.1373

Van Dierendonck, D. (2011). Servant leadership: A review and synthesis. Journal of Management, 37(4), 1228-1261. http://dx.doi.org/10.1177/0149206310380462

Vanderpyl, T.H. (2012). Servant leadership: A case study of a Canadian health care innovator. Journal of Healthcare Leadership, 4, 9-16. http://dx.doi.org/10.2147/ JHL.S28810

Vondey, M. (2010). The relationships among servant leadership, organizational citizenship behavior, person-organization fit, and organizational identification citizenship behavior, person-organization fit, and organi
International Journal of Leadership Studies, 6(1), 1-27.

Winston, B.E., \& Hartsfield, M. (2004). Similarities between emotional intelligence and servant leadership. Proceedings of the 2004 Servant Leadership Research Roundtable, Regent University, School of Leadership Studies. Retrieved Roundtable, Regent University, School of Leadership Studies. Retrieved
February 02, 2013, from http://www.regent.edu/acad/global/publications/sl_ February 02, 2013, from http://www.regent.edu/aca
proceedings/2004/winston_emotional_intelligence.pdf 